\title{
Evaluation of sanitary quality of goat milk in dairy industries from the Cariri region, state of Paraíba
}

\author{
A valiação da qualidade sanitária do leite de cabra em indústrias leiteiras dla região do Cariri, \\ estado da Paraíba \\ Evaluación de calidad sanitária de leche de cabra em industrias lácteas de la región del Cariri, \\ estado de Paraíba
}

Iara Nunes de Siqueira ORCID: https://orcid.org/0000-0001-9972-0064 Federal University of Campina Grande, Brazil E-mail: nunesdesiqueiraiara@gmail.com

Aline Antas Cordeiro Cavalcanti ORCID: https://orcid.org/0000-0002-0904-1517 Federal University of Campina Grande, Brazil E-mail: aline.antas@gmail.com

Joyce Galvão de Souza ORCID: https://orcid.org/0000-0001-5492-6317 Federal University of Campina Grande, Brazil E-mail: joycegalvaosouza@gmail.com

Filipe Jordão Pereira de Medeiros ORCID: https://orcid.org/0000-0003-3099-5929 Federal University of Campina Grande, Brazil E-mail: filipejordaomedvet@gmail.com João Carlos Taveira

ORCID: https://orcid.org/0000-0001-9512-8549 Federal University of Campina Grande, Brazil E-mail: apenas_xx@hotmail.com Samuel Fernandes Garcia ORCID: https://orcid.org/0000-0003-4447-6716 Federal University of Campina Grande, Brazil

E-mail: samuelfernandes1998@hotmail.com

Claudia Morgana Soares

ORCID: https://orcid.org/0000-0002-2726-5709 Integrated Colleges of Patos, Brazil E-mail: claudiamorganavet@gmail.com

Suely Cristina Pereira de Lima Oliveira ORCID: https://orcid.org/0000-0002-9408-6364 Federal Institute of Paraíba, Brazil E-mail: suely.oliveira@ifpb.edu.br

Abrahão Alves de Oliveira Filho ORCID: https://orcid.org/0000-0002-7466-9933 Federal University of Campina Grande, Brazil E-mail: abrahão.alves@professor.ufcg.edu.br Marcia Almeida de Melo ORCID: https://orcid.org/0000-0002-4229-9640 Federal University of Campina Grande, Brazil E-mail: marcia.melo@ufcg.edu.br

\begin{abstract}
The sanitary evaluation of equipment and hands is fundamental to investigate the presence of pathogens in the dairy industry. Then, this study aims to evaluate the sanitization of equipment, workers' hands, raw and pasteurized milk in goat milk dairies in the Cariri region, state of Paraíba. Collected 32 samples of four dairies represented by letters A, B, C, and D. The followings contents were analyzed: mesophiles, total and thermotolerant coliforms, Escherichia coli, Staphylococcus aureus, Samonella spp. and Listeria monocytogenes in the reception tank, pasteurization tank, packing machine, package, wall, workers' hand, and each dairy's raw and pasteurized milk. After isolation, 84 colonies were confirmed by MALDI TOF. The indicator microorganisms presented variations for the workers' hands, while A and B stayed within the patterns. For the equipment, only dairy B was within limits. They were out of the standard for mesophiles, total coliforms, and thermotolerant regarding raw and pasteurized milk. The microorganisms, the
\end{abstract}


Enterobacteriaceae family presented a higher frequency, with $77.38 \%$, and within this family, Escherichia coli, Klebsiella spp., and Enterobacter spp. were the most prevalent. Gram-positive corresponded to 22.62\%, Bacillus spp., Staphylococcus spp., Enterococcus spp., and Macrococcus caseolyticus. Listeria monocytogenes and Salmonella spp. were not isolated. These demonstrate failures in goat milk processing with pathogenic bacteria in several dairy plants, indicating the need to adjust the product's quality control.

Keywords: Dairy; Sanitization; Microorganisms.

\section{Resumo}

A avaliação sanitaria de equipamentos e mãos é fundamental para investigar a presença de patógenos na indústria de laticínios. Assim, este estudo teve como objetivo avaliar a higienização de equipamentos, mãos de trabalhadores, leite cru e pasteurizado em laticínios de leite de cabra na região do Cariri, estado da Paraíba. Coletaram-se 32 amostras de quatro laticínios representados pelas letras A, B, C e D. Os seguintes conteúdos foram analisados: mesófilos, coliformes totais e termotolerantes, Escherichia coli, Staphylococcus aureus, Salmonella spp. e Listeria monocytogenes no tanque de recepção, tanque de pasteurização, máquina de embalagem, embalagens, paredes, mãos dos trabalhadores e leite cru e leite pasteurizado de cada laticínio. Após o isolamento, 84 colônias foram confirmadas por MALDI TOF. Os microrganismos indicadores apresentaram variações para as mãos dos trabalhadores, enquanto A e B permaneceram dentro dos padrões. Para o equipamento, apenas o leite B estava dentro dos limites. Eles estavam for a do padrão para mesófilos, coliformes totais e termotolerantes em relação ao leite cru e pasteurizado. Os microrganismos,da família Enterobacteriaceae, apresentaram maior frequência, com 77,38\%, e dentro desta família, Escherichia coli, Klebisiella spp. e Enterobacter spp. foram os mais prevalentes. Gram-positivos corresponderam a 22,62\%, Bacillus spp., Staphylococcus spp., Enterococcus spp., Macrococcus caseolyticus, Listeria monocytogenes e Salmonella spp. não foram isolados. Foram demonstradas falhas no processamento do leite de cabra com bactérias patogênicas em várias fábricas de laticínios, indicando a necessidade de ajustar o controle de qualidade do produto.

Palavras-chave: Laticínio; Higienização; Microrganismos.

\section{Resumen}

La evaluación sanitaria de equipos y manos es fundamental para investigar la presencia de patógenos en la industria láctea. Luego, este studio tiene como objetivo evaluar la higienización de equipos, manos de trabajadores, leche cruda y pasteurizada en lecherías de leche de cabra en la region de Cariri, estado de Paraíba. Se recolectaron 32 muestras de cuatro lecherías representadas por las letras A, B, C y D. Se analizaron los siguientes contenidos: mesófilos, coliforms totals y termotolerantes, Escherichia coli, Staphylococcus aureus, Salmonella spp. y Listeria monocytogenes en el tanque de recepción, tanque de pasteurización, empaquetadora, empaque, pared, manos de los trabajadores y la leche cruda y pasteurizada de cada lechería. Después del aislamiento, se confirmaron 84 colonias mediante MALDI TOF. Los microorganismos indicadores presentaron variaciones para las manos de los trabajadores mientras que A yB se mantuvieron dentro de los patrones. Para el equipo, solo la lechería B estaba dentro de los límites. Estaban fuera del estándar para mesófilos, coliformes totales y termotolerates con respect a la leche cruda y pasteurizada. Los microorganismos, la familia Enterobacteriaceae presentaron una mayor frecuencia, con 77,38\%, y dentro de esta familia, Escherichia coli, Klebisiella spp. y Enterobacter spp. fueron los más frecuentes. Los grampositivos correspondieron al 22,62\%, Bacillus spp., Staphylococcus spp., Enterococcus spp. y Macrococcus caseolyticus, Listeria monocytogenes y Salmonella spp. no estaban aislados. Estos demuestran fallas en el procesamiento de la leche de cabra con bacterias patógenas env arias plantas lecheras, lo que indica la necesidad de ajustar el control de calidad del producto.

Palabras clave: Lácteos; Higienización; Microorganismos.

\section{Introduction}

Cariri region in Paraíba, Brazilian Northeast, in the late 1990s was one of the poorest regions in Brazil. The area was one of the most significant socioeconomic problems in the country; a situation worsened during prolonged droughts due to precarious productive organization. The maintenance of the same scenario in the early 2000 s clarified the need for an intervention to promote deep transformations in the region's socioeconomic, environmental, and productive environment. It was then decided to implement a dairy goat program (Rodrigues; Quintans, 2015), which turned the state of Paraíba into the biggest goat milk producer in the country, producing more than 5.5 million liters of milk per year, according to the Brazilian Institute of Geography and Statistics (IBGE) (2018).

The goat milk is rich in vitamins and minerals, appropriate to the elderly, sick, and children's diet since it has digestion and absorption twice as fast as cow's milk (Mendes; Silva; Abrantes, 2009; Cenaci et al., 2011). It is easily digested and has a high nutritional value with many probiotics, including lactic acid bacteria (Garcia et al., 2014). However, milk must 
pass through reasonable quality control to be competitive in the market, establishing a production system that prioritizes competitiveness and security for consumers (Rosa et al., 2017).

Due to its high nutritional value, goat milk is ideal for microorganisms' growth and multiplication. Besides primary contamination during animal husbandry, there are critical points during the dairy production chain, such as processing, transportation, and final product storage (Weschenfelder et al., 2016; Agrimonti et al., 2017).

According to the Center for Disease Control and Prevention (CDC) (2013), the workers are likely transmitters of food diseases pathogens when failures and mistakes are made. Equipment and utensils have this risk when they are not correctly sanitized, producing microbial multiplication (Andrade, 2008). Thus, the failure in hygiene care during the production chain may result in milk with high microbial content, questionable quality, and outside the standards required by legislation, which increase the probability of risks to human health (Silva et al., 2017). Therefore, it is essential to control and monitor the contamination, multiplication, and microbial survival in products, surfaces, equipment, utensils, and workers, contributing to the obtention of high-quality products (Andrade, 2008).

Then, this study aims to evaluate the presence of microorganisms in equipment, raw and pasteurized milk in goat dairies of the Cariri region in Paraíba.

\section{Methodology}

Four goat milk dairy industries from Cariri in Paraíba were selected, identified as A, B, C, and D. These dairy industries provide milk for the Food Acquisition Program (FAP). Samples were collected from each dairy's products, one from the cooling tank, one from the pasteurization tank, one from the packing machine, one from the packages, one from the worker's hand, and one from the wall. Two milk samples per dairy were selected to evaluate the quality, one from the raw milk, obtained from the cooling tank (from the aggregate), and the other from the milk after the pasteurization process. The collection was repeated four times, totalizing 32 samples.

The collection of material from utensils was made after the cleaning procedure. A sterile swab with a rod of $12 \mathrm{~cm}$ moistened in peptone water solution at $0.1 \%$ was rubbed for the samples of surfaces. The size of the surface evaluated with $100 \mathrm{~cm}^{2}$ was delimited with a sterilized mold. The swab was applied with constant pressure with rotating movements, in an inclination of about $30^{\circ}$ from left to right initially and then from right to left. The handled part of the swab was broken in the inner edge of the flask with $10 \mathrm{ml}$ peptone water containing the dilution solution. After that, the plating of aliquots was conducted in the appropriate culture medium (Andrade, 2008).

A sterile swab with a $12 \mathrm{~cm}$ rod moistened in a solution of peptone water at $0.1 \%$ was used for the worker's hands, rubbing the cotton three times towards each finger from the fist. After this, beginning from the fist, the swab was rubbed between the fingers, returning to the fist. The microorganisms collected were transferred to a pipe with $10 \mathrm{ml}$ of the peptone water solution (Andrade, 2008). Then, dilutions were made to the adequate media for each microorganism.

For the standard counting of viable mesophilic microorganisms, decimal dilutions were prepared using peptone water at $0.1 \%$. Then, $1 \mathrm{ml}$ of each dilution of $10^{0}$ to $10^{3}$ was used for utensils, workers' hands, and pasteurized milk, and of $10^{1}$ to $10^{4}$ for raw milk, which was deposited in the bottom of sterilized Petri plates in duplicate, distributed in two series, and 15 to $17 \mathrm{ml}$ of standard agar was added (Swanson et al. 1992). After homogenizing and solidifying agar at room temperature, the plates were incubated at $35^{\circ} \mathrm{C}$ per 48 hours to count the mesophilic microorganisms. According to the standard technique, the counts were performed with a colony counter, using plates with 25 to $250 \mathrm{CFU} / \mathrm{mL}$ (Colony Forming Units per milliliter). In the negative results for this interval, the obtained results were considered as estimated.

For enumeration of total coliforms and thermotolerant, $25 \mathrm{ml}$ of the sample was added in $225 \mathrm{~mL}$ of buffered peptone water at $0.1 \%$. The analysis was conducted with the multiple tube test (APHA, 2001). The sample was diluted, and the aliquots 
were transferred to test tubes containing Lauryl Tryptose Broth and incubated at $37^{\circ} \mathrm{C}$ per $24-48 \mathrm{~h}$. To confirm the results, the test tubes that presented positive results were transferred to a test tube containing Brilliant Green Bile Lactose Broth $2 \%$ and EC broth, which have been incubated at 37 and $45^{\circ} \mathrm{C}$ per 24 and $48 \mathrm{~h}$, respectively. The samples' densities of total coliforms and thermotolerant were obtained in table Most Likely Number (MLN) (APHA, 2001).

The presence of Escherichia coli was confirmed by the inoculation of aliquots from the positive tubes for thermotolerant coliforms into plates containing eosin methylene blue agar (EMB). The typical colonies were transferred to tubes containing plate count agar (PCA), incubated at $37^{\circ} \mathrm{C}$ per 24 hours, and then submitted to phenotypical characterization through indole, citrate, and MR-VP tests (APHA, 2001).

For count of coagulase-positive staphylococcal, $25 \mathrm{ml}$ of the sample was added in $225 \mathrm{ml}$ of peptone water at $0.1 \%$ (Acumedia) for milk, following APHA (2001). For the swabs of the utensils, an aliquot of $1 \mathrm{ml}$ of peptone water was removed, and decimal dilutions were made. The decimal dilutions of the samples were inoculated in a Baird Parker agar, supplemented with com egg yolk and potassium tellurite, and incubated at $37^{\circ} \mathrm{C}$ per $48 \mathrm{~h}$. After incubation, a presumptive count of the colony-forming units (CFU) was conducted. The presumptive colonies were selected and transferred to a Brain Heart Infusion broth; the confirmation was provided by phenotypic tests of Gram coloring, catalase, and coagulase production.

For Salmonella spp. research, $25 \mathrm{ml}$ of the sample was added in $225 \mathrm{ml}$ of peptone water at $0.1 \%$ (Acumedia). For the swabs of the utensils, an aliquot of $1 \mathrm{ml}$ of peptone water was removed, and decimal dilutions were conducted. For selective enrichment, aliquots were transferred to test tubes containing Tetrathionate and Rappaport Vassiliadis broths, and the respective tubes were incubated at $37^{\circ} \mathrm{C}$ per $24 \mathrm{~h}$. Then, a selective medium, Salmonella differential agar, was used, incubated at $37^{\circ} \mathrm{C}$ per $24 \mathrm{~h}$. Colonies with typical characteristics of Salmonella spp. were submitted to phenotypic tests in TSI slant, Lysine Iron agar, Urea broth, indole, citrate, and MR-VP (APHA, 2001).

A total of $225 \mathrm{~mL}$ of Listeria enrichment broth (LEB-Oxoid) was added in $25 \mathrm{ml}$ of each sample. For the swabs of the utensils, $25 \mathrm{ml}$ of peptone water was removed and placed in the Listeria enrichment broth (LEB- Oxoid). Then, the Fraser broth was used for the selective enrichment and incubated at $37^{\circ} \mathrm{C}$ per $48 \mathrm{~h}$. Posteriorly, the inoculation was conducted in Oxford agar and set at $37^{\circ} \mathrm{C}$ per $48 \mathrm{~h}$. Typical colonies of Listeria were submitted to phenotypical identification based on Gram coloring, catalase production, motility, and carbohydrate fermentation.

A total of 84 isolated colonies were submitted to identification using matrix-assisted laser desorption/ionization time-offlight mass spectrometry (MALDI-TOF MS), following the protocol described by Barcelos et al. (2019). The research methodology and organization carried out in accordance with Pereira, et al., (2018).

\section{Results and Discussion}

The microbiological results are presented in Table 1. In total, 84 isolates were identified. Escherichia coli, Klebsiella spp., and Enterobacter spp. were the most frequent microorganisms. Pseudomonas aeruginosa, Proteus mirabilis, Serratia marcescens, and Providencia had a lower frequence. Among the isolates of Klebsiella, the identified species were K. oxytoca and K. Pneumoniae. The isolates of Enterobacter spp. were E. Asburiae, E. cloacae, and E. Kobei. Only 11 samples were Gram-positive bacteria, among them Staphylococcus spp., Bacillus spp., Enterococcus spp., and Macrococcus caseolyticus. 
Table 1 - Microorganisms identified by MALDI-TOF MS and their occurrence in dairy products' samples.

\begin{tabular}{lcc}
\hline Microorganisms & N. of isolates & Frequency(\%) \\
\hline Escherichia coli & 22 & 26.19 \\
Klebsiella (pneumonaie e oxytoca) & 19 & 22.61 \\
Enterobacter (asburiae, cloacae e kobei) & 15 & 17.85 \\
Pseudomonas aeruginosa & 8 & 9.52 \\
Enterococcus (faecium, faecalis) & 6 & 7.14 \\
Proteus & 6 & 7.14 \\
Bacillus (subtilis e megaterium) & 2 & 2.38 \\
Serratia (marcescens) & 2 & 238 \\
Staphylococcus (aureus e epidermidis) & 2 & 2.38 \\
Macrococcus caseolyticus & 1 & 1.19 \\
Providencia & 1 & 1.19 \\
Total & 84 & 100 \\
\hline
\end{tabular}

Fonte: Autores.

The results of indicators microorganisms are in Table 2. According to Andrade (2008), there are no patterns or specifications for the microbial count in workers' hands; it is only determined scales used to define the hygienic-sanitary conditions for mesophiles and coliforms between $10^{3}$ and $10^{4} \mathrm{CFU} /$ hand. According to the data found in this study, the mesophiles in workers' hands in all the dairies studied are within the patterns. Furlan and Valejo (2017) found unsatisfactory results for mesophiles in $80 \%$ of the hands of workers who collected milk in rural properties in Paraná. This inadequate manipulation and carelessness concerning hygiene standards contribute to higher contamination by pathogenic microorganisms (Mello et al., 2010).

As occurs with workers' hands' hygiene, Brazil does not have legislation with microbiological standards for equipment and utensils. Many researchers follow the recommendations of the World Health Organization (WHO) and Pan American

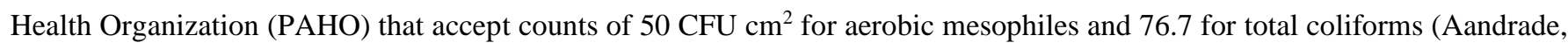
2008). The utensils evaluated regarding mesophiles, the pasteurization tank, the packaging machine, and the reception tank presented counts out of standards for mesophiles in dairies A, C, and D. Dairy B every had all evaluated aspects within the counts established by the international legislation.

The mesophiles patterns for raw goat milk are regulated in Brazil by IN n. October 37, 2000 that established a maximum value of $5 \times 10^{5} \mathrm{CFU} / \mathrm{mL}$ (BRASIL, 2000). In this study, the raw milk from Cariri, Paraíba, presented high mesophilic counts in dairies A, B, and C. Only dairy D was within the patterns, but with values close to the limits established by legislation. Such findings corroborate the values presented by Coelho et al. (2018), who found mesophiles values from $5,3 \times 10^{2}$ to $5,3 \times 10^{5}$. The same authors state that such values are due to the lack of hygiene during milking and the delay in the cooling process. Padua et al. (2019) found an average of 7,6x10 $\mathrm{CFU} / \mathrm{mL}$, a value within the standards.

The mesophiles count for pasteurized milk is within limits established, except for dairy $\mathrm{C}$, which obtained values of 2,5x $10^{5} \mathrm{CFU} / \mathrm{ml}$. The group of mesophilic bacteria is constituted by Enterobacteriaceae, Clostridium spp., Streptococcus spp., Corynebacterium spp., etc. Enterobacteriaceae are the most significant and dangerous, causing intestinal and urinary infection, sepsis, and even the death of red blood cells due to lactic acid production (Furlan; Valejo, 2017).

The total coliforms and thermotolerant in workers' hands were within the patterns, according to Andrade (2008). The values of total coliforms varied from $<0.3$ to $2.3 \mathrm{MLN} / \mathrm{mL}$ and from $<0.3$ to $1.5 \mathrm{MLN} / \mathrm{mL}$ for thermotolerant coliforms. Such 
data corroborate those found by Candeira et al. (2020) and Figueiredo et al. (2016), who found satisfactory results for workers' hands in a dairy farm in the state of Pará. Concerning equipment and utensils, all dairies in this study are within the standards. Values varied from $<0.3$ to 24 for total coliforms and thermotolerant, corroborating Candeira et al. (2020), who found satisfactory results while evaluating a dairy farm's equipment.

The total coliforms are composed of bacteria from the Enterobacteriaceae family that can ferment lactose and produce gas when incubated at $35-37^{\circ} \mathrm{C}$ per 48 hours (Mendes et al., 2009). The thermotolerant coliforms are characterized by their capacity to ferment lactose with acid and gas production at the temperature of $45^{\circ} \mathrm{C}$ (Coelho et al., 2018). These microorganisms constitute a subgroup of total coliforms, in which their presence indicates the probability of contamination with fecal material (Mendes et al., 2009). A study by Dutra et al. (2014) with raw goat milk at different storage temperatures found a variation from $<3$ to $>1100 \mathrm{MLN} / \mathrm{mL}$. Although a standard for coliforms in raw milk does not exist, according to Coelho et al. (2018), the presence of bacteria from the coliforms group in samples of raw goat milk may indicate milk contamination.

The results of total and thermotolerant coliforms of pasteurized milk varied from 2.1 to $240 \mathrm{MLN} / \mathrm{mL}$ and 2.1 to 460 $\mathrm{MLN} / \mathrm{mL}$, respectively. According to the legislation, the established limit is $2 \mathrm{MLN}$ for total coliforms and $0 \mathrm{MLN} / \mathrm{ml}$ for thermotolerant coliforms, demonstrating that all evaluated dairies are outside the standards for total coliforms and thermotolerant (BRASIL, 2000).

Several studies found unsatisfactory sanitary quality while studying total coliforms and thermotolerant in pasteurized goat milk (Andrade et al., 2008; Maraschin et al., 2004; Silva et al., 2017;). However, Santos et al. (2012) and Fonseca et al. (2006) did not found thermotolerant coliforms in pasteurized milk.

The coliforms are destroyed by pasteurization. Their presence in pasteurized milk indicates the need for more effective time and temperature control in the pasteurizer, better selection of raw milk suppliers, and sanitization of utensils with milk after pasteurization. This fact clarifies the need for revaluation of these steps to identify and diagnose all sources of contamination. (Silva et al., 2008; Martins et al., 2012).

The isolated colonies of utensils, raw and pasteurized milk analyzed in this study were submitted to identification by MALDI-TOF MS. In Table 3, it is observed that of 24 samples from equipment and workers' hands, $66.67 \%$ were contaminated. According to Andrade (2008), on the surfaces of utensils, the pathogens must be absent. The packages were one of the places with the highest presence of pathogenic microorganisms in all dairies. There is a direct relation between them because employees are responsible for handling the packaging, making them critical control points within the dairy. Dairy D was the most contaminated, with the presence of pathogenic microorganisms in all the evaluated places. Dairy $\mathrm{C}$ presented a lower frequency of contamination, with microorganisms on workers' hands, pasteurization tank, and packages. 
Table 2 - Enumeration of total coliforms, thermotolerant and mesophiles in equipment, raw and pasteurized goat milk of the Cariri region in Paraíba from January to February 2019

\begin{tabular}{|c|c|c|c|c|c|c|c|c|c|}
\hline Microorganisms & Dairy & Workers' hand & $\begin{array}{l}\text { Reception } \\
\text { tank }\end{array}$ & $\begin{array}{c}\text { Pasteurization } \\
\text { tank }\end{array}$ & $\begin{array}{l}\text { Packaging } \\
\text { machine }\end{array}$ & Package & Wall & Raw Milk & $\begin{array}{c}\text { Pasteurized } \\
\text { milk }\end{array}$ \\
\hline & $\mathrm{A}$ & $7.4 \times 10^{2}$ & $1.7 \times 10^{2}$ & $5.5 \times 10^{2}$ & Negative & $3.7 \times 10^{2}$ & Negative & $>2.5 \times 10^{4}$ & $9.0 \times 10^{3}$ \\
\hline Mesophiles & $\mathrm{B}$ & $5.5 \times 10^{1}$ & $2.4 \times 10^{1}$ & $<2.5 \times 10^{1}$ & $<2.5 \times 10^{1}$ & Negative & Negative & $>2.5 \times 10^{4}$ & $4.3 \times 10^{2}$ \\
\hline \multirow[t]{3}{*}{$\mathrm{CFU} / \mathbf{c m}^{2}$} & $\mathrm{C}$ & $4.5 \times 10^{3}$ & $>2.5 \times 10^{2}$ & $5.1 \times 10^{4}$ & Negative & $4.3 \times 10^{3}$ & $>2.5 \times 10^{2}$ & $>2.5 \times 10^{4}$ & $>2.5 \times 10^{3}$ \\
\hline & $\mathrm{D}$ & $1.3 \times 10^{3}$ & $4.6 \times 10^{2}$ & $>2.5 \times 10^{2}$ & $<2.5 \times 10^{1}$ & $2.7 \times 10^{2}$ & $1.1 \times 10^{3}$ & $4.8 \times 10^{5}$ & $8.3 \times 10^{2}$ \\
\hline & A & 2.3 & 2.3 & 0.9 & $<0.3$ & 0.9 & $<0.3$ & $2.4 \times 10^{5}$ & 460 \\
\hline Total Coliforms & B & $<0.3$ & $<0.3$ & $<0.3$ & $<0.3$ & $<0.3$ & $<0.3$ & $2.4 \times 10^{5}$ & $>240$ \\
\hline \multirow[t]{2}{*}{ MLN/cm² } & $\mathrm{C}$ & 1.5 & $<0.3$ & $<0.3$ & $<0.3$ & $<0.3$ & $<0.3$ & $2.4 \times 10^{5}$ & 2.1 \\
\hline & $\mathrm{D}$ & $<0.3$ & 24 & $<0.3$ & $<0.3$ & 1.5 & $<0.3$ & $2.4 \times 10^{5}$ & 110 \\
\hline \multirow{4}{*}{$\begin{array}{c}\text { Thermotolerant } \\
\text { Coliforms } \\
\text { MLN/cm }{ }^{2}\end{array}$} & A & 0.4 & $<0.4$ & 0.4 & $<0.3$ & 0.9 & $<0.3$ & $2.4 \times 10^{5}$ & 460 \\
\hline & B & $<0.3$ & $<0.3$ & $<0.3$ & $<0.3$ & $<0.3$ & $<0.3$ & $1.5 \times 10^{4}$ & 110 \\
\hline & $\mathrm{C}$ & 1.5 & $<0.3$ & $<0.3$ & $<0.3$ & $<0.3$ & $<0.3$ & $2.4 \times 10^{5}$ & 2.1 \\
\hline & $\mathrm{D}$ & $<0.3$ & 24 & $<0.3$ & $<0.3$ & 4.3 & $<0.3$ & $2.4 \times 10^{5}$ & 110 \\
\hline
\end{tabular}

Fonte: Autores. 
Research, Society and Development, v. 10, n. 12, e596101220735, 2021

(CC BY 4.0) | ISSN 2525-3409 | DOI: http://dx.doi.org/10.33448/rsd-v10i12.20735

Table 3 - Bacterial species identified by MALDI TOF in equipment, raw and pasteurized goat milk of dairies in the Cariri region, Paraíba, from January to February 2019.

\begin{tabular}{|c|c|c|c|c|}
\hline \multirow[b]{2}{*}{ Site } & \multicolumn{4}{|c|}{ Dairy industries } \\
\hline & $\mathbf{A}$ & $\mathbf{B}$ & $\mathbf{C}$ & $\mathbf{D}$ \\
\hline Workers' hand & $\begin{array}{l}\text { Klebsiella pneumoniae } \\
\text { Bacillus megaterium }\end{array}$ & $\begin{array}{c}\text { Enterobacter cloacae } \\
\text { Staphylococcus epidermidis }\end{array}$ & $\begin{array}{c}\text { Klebsiella pneumoniae } \\
\text { Bacillus subtilis }\end{array}$ & Providencia \\
\hline Reception tank & Proteus mirabilis & Klebsiella pneumoniae & - & $\begin{array}{c}\text { Enterobacter cloacae } \\
\text { Pseudomonas aeruginosa } \\
\text { Enterococcus spp. }\end{array}$ \\
\hline Pasteurization tank & - & Enterobacter cloacae & Pseudomonas aeruginosa & $\begin{array}{c}\text { Klebsiella pneumoniae } \\
\text { Proteus mirabilis } \\
\text { Enterococcus spp. }\end{array}$ \\
\hline Packaging machine & Pseudomonas aeruginosa & - & - & $\begin{array}{c}\text { Enterobacter cloacae } \\
\text { Proteus mirabilis } \\
\text { Enterococcus spp. }\end{array}$ \\
\hline Packages & Klebsiella pneumoniae & $\begin{array}{c}\text { Enterobacter cloacae } \\
\text { Serratia marcescens }\end{array}$ & Pseudomonas aeruginosa & $\begin{array}{l}\text { Enterobacter cloacae } \\
\text { Serratia marcescens } \\
\text { Enterococcus spp. }\end{array}$ \\
\hline Wall & - & - & - & - \\
\hline Raw milk & $\begin{array}{c}\text { Escherichia coli } \\
\text { Enterobacter cloacae } \\
\text { Klebsiella pneumoniae } \\
\text { Proteus mirabilis } \\
\text { Staphylkococcus aureus }\end{array}$ & $\begin{array}{c}\text { Escherichia coli } \\
\text { Klebsiella oxytoca } \\
\text { Klebsiella pneumoniae } \\
\text { Pseudomonas aeruginosa }\end{array}$ & $\begin{array}{c}\text { Escherichia coli } \\
\text { Klebsiella oxytoca } \\
\text { Klebsiella pneumoniae } \\
\text { Enterococcus spp. }\end{array}$ & $\begin{array}{c}\text { Escherichia coli } \\
\text { Enterobacter cloacae } \\
\text { Enterobacter kobei } \\
\text { Enterobacter asburie } \\
\text { Enterococcus } \text { spp. }\end{array}$ \\
\hline Pasteurized milk & $\begin{array}{l}\text { Klebsiella pneumoniae } \\
\text { Enterobacter kobei }\end{array}$ & $\begin{array}{c}\text { Escherichia coli } \\
\text { Klebsiella pneumoniae } \\
\text { Proteus mirabilis } \\
\text { Pseudomonas aeruginosa }\end{array}$ & $\begin{array}{l}\text { Escherichia coli } \\
\text { Enterococcus spp. }\end{array}$ & $\begin{array}{c}\text { Escherichia coli } \\
\text { Enterobacter cloacae }\end{array}$ \\
\hline
\end{tabular}

Fonte: Autores 
Of the 84 isolates obtained in goat milk dairies of the Cariri region, 77.38\% are from the Enterobacteriaceae family, with six different genera. Escherichia coli, Klebsiella spp., and Enterobacter spp. were the species with the highest isolation frequency, comprising $66.66 \%$ of the isolates. These microorganisms are originated from the gastrointestinal tract of humans and animals. They are considered good indicators of sanitary food conditions (Cruz et al., 2019). They are also able to generate protein and lipid breakdown, contributing to economic losses and waste (Baylis et al., 2011) due to enzyme production

In Europe, the Enterobacteriaceae Family has been used as an indicator of dairy quality and the sanitary conditions of dairy products and their processing environment (Hervet et al., 2016). Then, it is used as a marker of contamination and sanitary conditions during the processing and post-processing because its presence can indicate enteric pathogens (Moraes et al., 2009; Okura; Marin, 2014). Escherichia coli was found only in raw and pasteurized goat milk, indicating failures in the dairies' quality control. The contamination mechanisms can be cross-contamination between raw and cooked food, utensils not disinfected, and unsanitized workers' hands. They are also considered indicators of fecal contamination (Silva Júnior, 2014).

Klebsiella spp. and Enterobacter spp. were found in several goat milk processing environments, including workers' hands, reception tank, pasteurization tank, package, raw, and pasteurized milk. This fact indicates gaps in the cleaning process that need to be re-evaluated to secure sanitary product quality. Klebsiella spp. causes mastitis and is commonly found in the environment, water, beds, and soils. The two most frequent species are K. pneumoniae and K. oxytoca (Podschum; Ullmann, 1998; Cerqueira et al., 2011Santos et al., 2019; Santos Júnior et al., 2019;).

Enterobacter spp. is widespread, composing the human and animal gastrointestinal tract flora, and sometimes becomes an opportunistic pathogen (Mezzatesta; Gona; Stefani, 2012). Its clinical significance increased during the last years, and it is now recognized as a significant nosocomial pathogen, especially for intensive care patients (for example, causing sepsis). These microorganisms are widely spread in the environment occurring in soil and sewer (Denton, 2007; Wisplinghoff et al., 2004).

Listeria monocytogenes and Salmonella spp. were not found in the samples studied. However, other studies demonstrate their presence in the dairy industry (Monte et al., 2016; Zegarra et al., 2009). These microorganisms are associated with disease outbreaks related to milk intake (Cruz et al., 2019).

The other genera, identified as Bacillus spp., Staphylococcus spp., Enterococcus spp., and Macrococcus, are Grampositive microorganisms. Many of these species are pathogens with the potential to form biofilms (Alonso \& Kabuki, 2019; Wang et al., 2019; Novoa et al., 2018; Lira et al., 2016). When adhered to utensils, their elimination becomes more complex, and they may function as sources of pathogenic microorganisms for processed products.

\section{Conclusion}

The presence of several pathogenic bacterial species in equipment and raw and pasteurized goat milk in dairies of the Cariri region in Paraíba reveal failures in the cleaning process. The re-evaluation of the sanitary practices and the quality control adopted in dairies for processed products is necessary to ensure the final product's sanitary quality, and more studies of this type can be carried out to see if there have been improvements.

\section{Acknowledgments}

To CAPES for granting the scholarship. 


\section{References}

Agrimonti, C., Botari, B., Sardaro, M. L. S. \& Marmiroli, N. (2017). Application of realtime PCR (qPCR) for characterization of microbial populations and type of milk in dairy food products. Critical Reviews in Food Science and Nutrition, 53 (7): 1157- 1226.

Alonso, V. P. P. \& Kabuki, D. Y. (2019). Formation and dispersal of biofilms in dairy substrates. International Journal of Dairy Technology, 72 (3), $472-478$.

American Public Health Association - APHA. (2001). Compendium of methods for the microbiological examination of foods. (4th ed.), American Public Health Association.

Andrade, N. J. (2008). Higiene na indústria de Alimentos: Avaliação e controle da adesão e formação de biofilmes bacterianos. Varela

Andrade, P. V. D., Souza, M. R., Penna, C. F. A. M. \& Ferreira, J. M. (2008). Características microbiológicas e físico-químicas do leite de cabra submetido à pasteurização lenta pós-envase e ao congelamento. Ciência Rural, 38 (5), 1424-1430.

Barcelos, M. M., Martins, L., Grenfell, R. C., Juliano, L., Anderson, K. L., Santos, M. V. \& Gonçalves, J. L. (2019). Comparison of standard and on-plate extraction protocols for identification of mastitis-causing bacteria by MALDI-TOF MS. Brazilian Journal of Microbiology, $50,849-857$.

Baylis, C., Uyttendaele, M., Joosten, H. \& Davies, A. (2011). The Enterobacteriaceae and their significance to the food industry. ILSI Europe, Brussels. www.ilsi.eu.

Brasil. Instrução Normativa n 37, de 31 de outubro de (2000). Regulamento Técnico de Identidade e Qualidade de Leite de Cabra. Brasília, 2000.

Candeira, R. P., Lacerda, L. M., Silva, A. S., Galeno, L. S., Moreno, B. F. S. \& Durães, C. C. (2020). Evaluation of the hygienic-sanitary conditions of a dairy localized in the Island of São Luís, Maranhão. Arquivos do Instituto Biológico, 87, 1-5.

CDC - Centers for Disease Control and Prevention. Antibiotic Resistance Threats in the United States (2013). U.S. Department of Health and Human Services.

Cenaci, D. B., Furtado, M. A. M., Bell, M. J. V., Pereira, M. S., Amigo, L. \& Pinto, M. A. O. (2011). Aspectos composicionais, propriedades funcionais, nutricionais e sensoriais do leite de cabra: uma revisão. Revista do Instituto de Laticínios Cândido Tostes, 66 (382), 12-20.

Cerqueira, A. S., Machado, P., Marto, J., Lito, L., Melo-Cristino, J. \& Duarte, A. (2011). Persistência de Klebsiella pneumoniae em doentes de unidades pediátricas do Hospital de Santa Maria, em Lisboa. Acta Pediátrica, 42 (2), 49-53.

Coelho, M. C. S. C., Rodrigues, B. R., Coelho, M. I. S., Libório, R. C., Costa, F. F. P. \& Silva, G. L. (2018). Características físico-química e microbiológica do leite de cabra produzido em Petrolina-PE. Agropecuária Científica no Semiárido, 14 (3), 175-182.

Cruz, A. G., Zacarchenco, P. B., Oliveira, C. A. F. \& Corassin, C. H. (2019). Microbiologia, higiene e controle de qualidade no processamento de leite e derivados. 1 ed. Rio de janeiro: Elsevier.

Denton, M. (2007). Enterobacteriaceae. International Journal of Antimicrobial Agents, 29 (3), 9-22.

Dutra C. M. C., Svierk, B., Ribeiro, M. E. R., Pinto, A. T., Zanela, M. B. \& Schmidt, V. (2014). Parâmetros de qualidade do leite de cabra armazenado sob frio. Arquivos do Instituto Biológico, 81 (1), 36-42.

Figueiredo, E. L., Melo, J. K. L. \& Neves, N. C. O. (2016). Diagnóstico higiênico-sanitário e da qualidade microbiológica de produtos lácteos em um laticínio localizado em Tucuruí-Pará. Revista do Instituto de Laticínios Cândido Tostes, 71 (2), 53-64.

Fonseca, C. R., Porto, E., Dias, C. T. S., \& Susin, I. (2006). Qualidade do leite de cabra in natura e do produto pasteurizado armazenados por diferentes períodos. Food Science and Technology, 26 (4), 944-949.

Furlan, M. F. \& Valejo, N. M. (2017). Avaliação da ocorrência de bactérias mesófilas no leite cru e análise do enquadramento das boas práticas de manuseio feito pelos produtores rurais de Ji-Paraná. Journal of basic Education, Techinical and Technological, 4 (2), $30-42$.

Hervert, C. J., Alles, A. S., Martin, N. H., Boor, K. J. \& Wiedmann, M. (2016). Evaluation of different methods to detect microbial hygiene indicators relevant in the dairy industry. Journal Dairy Science, 99, 7033-7042.

IBGE - Instituto Brasileiro de Geografia e Estatística. (2018). Censo Agropecuário. https://censos.ibge.gov.br/agro/2017.

Lira, M. C., Givisiez, P. E. N., Sousa, F. G. C., Magnani, M., Souza, E. L., Spricigo, D. A. \& Gebreyes, W. A. (2016). Biofilm-forming and antimicrobial resistance traits of staphylococci isolated from goat dairy plants. The Journal of Infection in Developing Counties, 10 (9), 932-938.

Maraschin, F. L., Pinto, A. T. \& Schmidt, V. (2004). Presença de coliformes e parâmetros físico-químicos de leite de cabra integral pasteurizado de um laticínio sob inspeção estadual, no Rio Grande do Sul. Pesquisa Agropecuária Gaúcha, 10 (2), 73-77.

Martins, J. N., Santos, D. C., Oliveira, E. N. A. \& Albuquerque, E. M. B. (2012). Qualidade microbiológica de leites pasteurizados comercializados na cidade de Morada Nova, Ceará. Revista Verde [online], 7 (3), 119-123.

Mendes, C. G., Silva, J. B. A. \& Abrantes, M. R. (2009). Caracterização organoléptica, físico-química, e microbiológica do leite de cabra: uma revisão. Acto Veterinaria Brasilica, 3 (1), 5-12.

Mello, A. G., Gama, M. P., Marin, V. A. \& Colares, L. G. T. (2010). Conhecimento dos manipuladores de alimentos sobre boas práticas nos restaurantes públicos populares do Estado do Rio de Janeiro. Brazilian Journal of Food Technology, 13 (1), 60-68.

Mezzatesta, M. L., Gona, F. \& Stefani, S. (2012). Enterobacter cloacae complex: clinical impact and emerging antibiotic resistance. Future Microbiology, 7 (7), 887-902. 
Monte, D. F. M., Lopes Júnior, W. D., Oliveira, C. J. B. \& Moura, J. F. P. (2016). Indicadores de qualidade microbiológica do leite caprino produzido na Paraíba. Agropecuária Científica no Semiárido, 12 (4), 354-358.

Moraes, P. M., Viçosa, G. N., Yamazi, A. K., Ortolani, M. B. T. \& Nero, L.A. (2009). Foodborne pathogens and microbiological characteristics of raw milk soft cheese produced and on retail sale in Brazil. Foodborne Pathogens and Disease, 6, 245-249.

Novoa, M. G. A., Moreno, I. M. M., Solis, V. O. A., Gonzalez, G. J. P., Guerreo, M. P. J. \& Lomeli, G. M. (2018). Biofilm formation by Staphylococcus aureus isolated from food contact surfaces in the dairy industry of Jalisco, Mexico. Journal of Food Quality, 2018, 1-8.

Okura, M. H. \& Marin, J. M. (2014). Survey of Minas frescal cheese from Southwest Minas Gerais for virulence factors and antimicrobial resistance in Escherichia coli isolates. Ciência Rural, 44, 1506-1511.

Padua, F. S., Couto, E. P., Nero, L. A. \& Ferreira, M. A. (2019). Qualidade físico-química e microbiológica de leite de cabra produzido no Distrito Federal. Ciência Animal Brasileira, 20 (1-9), e-43357.

Pereira, A. S., Shitsuka, D. M., Parreira, F. J. \& Shitsuka, R. (2018). Metodologia da Pesquisa Científica. [free e-book]. Santa Maria/RS. Ed. UAB/NTE/UFSM.

Podschun, R. \& Ullmann, R. (1998). Klebsiella spp. as nosocomial pathogens: epidemiology, taxonomy, typing methods, and pathogenicity factors. Clinical Microbiology Reviews, 11 (4), 589-603.

Rodrigues, A. \& Quintans, L. J. (2015). Importância da caprinocultura leiteira para o desenvolvimento do Cariri paraibano. Ciência Veterinária nos Trópicos, $18(2), 15-22$

Rosa, J. F., Domingues, L. S. P., Silva, R. H., Lima, H. G. \& Cereser, N. D. (2017). Pontos críticos de contaminação na produção leiteira. Expressa Extensão, $22(1), 90-103$.

Santos, D. C., Martins, J. N., Oliveira, E. N. A. \& Falcão, L. V. (2012). Caracterização de leite caprino comercializado na região do Vale do Jaguaribe, Ceará. Revista Verde, 7 (2), 289-295.

Santos Júnior, D. A. S., Matos, R. A. T., Melo, D. B., Garino Júnior, F., Simões, S. V. D. \& Neto, E. G. M. (2019). Etiologia e sensibilidade antimicrobiana in vitro de bactérias isoladas de cabras com mastite no sertão e cariri paraibano. Ciência Animal Brasileira, 20 , e-44848.

Santos, J. V. I., Lima Júnior, A. C., Araújo, T. G. P., Farias, J. P. \& Lisboa, A. C. C. (2019). Avaliação da qualidade do leite de cabra em uma propriedade no município de Monteiro - PB. Revista Craibeiras de Agroecologia, 4 (1), e7682.

Silva Júnior, E. A. (2014). Manual de controle higiênico-sanitário em serviços de alimentação. (7a ed.), Varela.

Silva, M. C. D., Silva, J. V. L., Ramos, A. C. S., Melo, R. O. \& Oliveira, J. O. (2008). Características microbiológicas e físico-químicas de leite pasteurizado destinado ao programa do leite no Estado de Alagoas. Ciência e Tecnologia Alimentar, 28 (1), 226-230.

Silva, J. B. P., Macêdo, C. S., Oliveira, S. M. S., Rangel, A. H. N. \& Mirmann, L. (2017). Qualidade microbiológica do leite caprino em propriedades rurais da região de Macaíba/RN. Revista do Instituto de Laticínios Cândido Tostes, 72 (2), 67-73.

Swanson, K. M. J., Busta, F. F., Peterson, E. H. \& Johnson, M. G. (1992). Colony count methods. In: American Public Health Association. Committee on microbiological methods for foods. Compedium of methods for the microbiological examination of foods. Washington: American Public Health Association. p. $75-95$.

Wang, B., Tan, X., Du, R., Zhang, L., Han, Y. \& Zhou, Z. (2019). Bacterial composition of biofilms formed on dairy processing equipment. Preparative Biochemistry and Biotechnology, 49 (5), 477-484.

Weschenfelder, S., Paim, M. P., Gerhardt, C. \& Wiest, J. M. (2016). Avaliação da rotulagem nutricional e das características físico-químicas e microbiológicas de diferentes marcas de leite pasteurizado e leite UHT. Boletim de Indústria Animal, 73 (1), 32-38.

Wisplinghoff, H., Bischoff, T., Tallent, S.M., Seifert, H., Wenzel, R.P. \& Edmond, M.B. (2004). Nosocomial bloodstream infections in US hospitals: analysis of 24,179 cases from a prospective nationwide surveillance study. Clinical Infectious Diseases, 39 (3), $309-317$.

Zegarra, J. J. Q., Botteon, R. C. C. M., Oliveira, B. C. R. S., Botteon, P. T. L. \& Souza, M. M. (2009). Pesquisa de microrganismos em utensílios, leite e queijos de produção artesanal em unidades de produção familiar no município de Seropédica, Rio de Janeiro. Ciência Animal Brasileira, 10 (1), $312-321$. 